\title{
Chromosomal Mapping and QTL Analysis of Resistance to Downy Mildew in Cucumis sativus
}

S. P. Zhang, M. M. Liu, and H. Miao, Institute of Vegetables and Flowers, Chinese Academy of Agricultural Sciences, Beijing 100081, China; S. Q. Zhang, College of Agriculture, Guizhou University, Guiyang 550025, China; Y. H. Yang and B. Y. Xie, Institute of Vegetables and Flowers, Chinese Academy of Agricultural Sciences, Beijing 100081, China; T. C. Wehner, Department of Horticultural Science, North Carolina State University, Raleigh, NC 27695-7609, U.S.A.; and X. F. Gu, Institute of Vegetables and Flowers, Chinese Academy of Agricultural Sciences, Beijing 100081, China

\begin{abstract}
Zhang, S. P., Liu, M. M., Miao, H., Zhang, S. Q., Yang, Y. H., Xie, B. Y., Wehner, T. C., and Gu, X. F. 2013. Chromosomal mapping and QTL analysis of resistance to downy mildew in Cucumis sativus. Plant Dis. 97:245-251.

Downy mildew of cucumber (Cucumis sativus), caused by Pseudoperonospora cubensis, is a major foliar disease worldwide. The cucumber inbred lines K8 (resistant to downy mildew) and K18 (susceptible) were used to study the inheritance of resistance to downy mildew. Chromosomal mapping of the resistance genes was completed to provide a theoretical basis for the resistance mechanisms and for marker assisted selection (MAS). Inoculation was used to test the level of resistance to $P$. cubensis in the $\mathrm{F}_{2}$ and $\mathrm{F}_{2: 3}$ families derived from the cross K8 $\times$ K18. Simple sequence repeat $(\mathrm{SSR})$ analysis, combined with bulked segregation analysis (BSA), was done with the DNA of $\mathrm{F}_{2}$ plants using 2,360 pairs of SSR primers. JoinMap Version 3.0 and MapInspect were used to construct SSR linkages and to verify the relationships between these SSR linkages and cucumber chromosomes.

Quantitative trait locus (QTL) analysis of downy mildew resistance was done using MapQTL Version 4.0. Inheritance of resistance to downy mildew in K8 was quantitative. Five QTLs for resistance to downy mildew were detected: $d m 1.1, d m 5.1, d m 5.2, d m 5.3$, and $d m 6.1$. The loci of $d m 1.1$ and $d m 6.1$ were on chromosomes 1 and 6, respectively. The loci of $d m 5.1, d m 5.2$, and $d m 5.3$ were on chromosome 5, and were linked. Six linked SSR markers for these five QTLs were identified: SSR31116, SSR20705, SSR00772, SSR11012, SSR16882, and SSR16110. Six and four nucleotide binding site (NBS)-type resistance gene analogs (RGAs) were predicted in the region of $d m 5.2$ and $d m 5.3$, respectively. These results will be of benefit for fine-mapping the major QTLs for downy mildew resistance, and for MAS in cucumber.
\end{abstract}

Downy mildew, powdery mildew, and Fusarium wilt are the three most significant diseases of cucumber (Cucumis sativus L.) in China (5). Downy mildew, caused by Pseudoperonospora $\mathrm{cu}$ bensis (Berk. \& Curt.) Rostov., has been reported on species of the genus Cucumis in 70 countries worldwide $(9,28,36,42,48)$. The disease has a short latent period, high secondary infection frequency, rapid spread, and year-round presence in many cucumber production areas $(9,10)$. Downy mildew can cause significant reductions in yields $(10,27)$, especially in protected culture such as greenhouse production. Probably the best method for controlling downy mildew in cucumber is the use of resistant cultivars. As a result, downy mildew resistance is one of the main objectives in cucumber breeding programs $(8,55)$.

After sources of downy mildew resistance have been identified, the next step is to determine the nature of inheritance of the resistance. The types of inheritance of downy mildew resistance genes have been determined $(1,8,12-14,21,43,44,53,59)$, but the conclusions vary. Some researchers reported that resistance to downy mildew in cucumber was quantitative. Cochran (8) concluded that resistance to downy mildew in the cultivar Bangalare was controlled by several genes. Jenkins (21) considered that there were one or two major genes and one or several minor genes controlling resistance. Zhang et al. (59) reported two major genes and several minor genes for resistance in Northern Chinese type cucumbers. Shimizu et al. $(43,44)$ and Doruchoowski and Lakowska-Ryk (13) reported three recessive genes for resistance in American processing type cucumbers and European greenhouse

Corresponding author: Xing-Fang Gu, E-mail: guxf@mail.caas.net.cn

Accepted for publication 26 August 2012.

http://dx.doi.org/10.1094/PDIS-11-11-0941-RE

(C) 2013 The American Phytopathological Society type cucumbers. Bai et al. (1) reported several genes in S94 (Northern Chinese type cucumber) using a population of recombinant inbred lines (RILs). Several studies reported that resistance was a qualitative trait controlled by a single gene. Resistance in 'Poinsett' (an inbred line) was reported to be controlled by the single gene $d m$, and $d m$ was linked to powdery mildew resistance $(14,53)$. Ding et al. (12) reported a single gene for resistance in cucumber. Given this diversity in reported inheritance of resistance to downy mildew in cucumber, additional studies are needed to help clarify these variations in inheritance of downy mildew resistance. One of the objectives of this study was to determine the inheritance of downy mildew resistance in the inbred line K8. K8 is a typical Northern Chinese type cucumber with resistance to powdery mildew (60) and downy mildew, and was derived from a Chinese Long cucumber hybrid.

Breeding cucumber for resistance to downy mildew requires evaluations in multiple locations and with replications to control environmental variation, including exposure to different isolates of the pathogen, and to make effective selections for resistance during years of crossing and inbreeding. It may be possible to select for resistance more efficiently using molecular, marker-assisted selection (MAS), than using just disease ratings. However, there are only a few reports on the molecular biology of downy mildew resistance in cucumber. Kennard et al. (23) screened two restriction fragment length polymorphism (RFLP) markers, CsC230/EcoR and CsC593/Dra, linked to $d m$ at genetic distances of 9.5 and 17.7 $\mathrm{cM}$, respectively. Meglic and Staub (32) reported an isoenzyme marker, $P g m$, linked to the $d m$ gene at $14 \mathrm{cM}$. Horejsi et al. (18) identified five random amplified polymorphic DNA (RAPD) markers linked to $d m$. The marker BC519 1100 was the closest at $9.9 \mathrm{cM}$. Ding et al. (12) reported the RAPD marker SPS18-561 was linked to the $d m$ gene at $7.85 \mathrm{cM}$. Bai et al. (1) detected four quantitative trait locus (QTLs) for downy mildew resistance in the inbred line S94, $d m 1.1, d m 1.2, d m 6.1$, and $d m 6.2$, which were mapped to linkage groups 1 and 6 . Seven sequence related amplified polymor- 
phism (SRAP) markers and one simple sequence repeat (SSR) marker were linked to these QTLs. The genetic distance for the SSR marker to $d m 1.1$ was $9.7 \mathrm{cM}$.

An efficient MAS system for downy mildew requires markers that have tight linkage to the resistance genes, combined with an assay that is easy and inexpensive to run (61). In previous studies, the main markers linked to cucumber downy mildew resistance were RFLP, RAPD, and SRAP types that are expensive and timeconsuming to measure, and involve the use of radioactive materials or markers with dominant expression $(12,18,23)$. These marker types are not cost-efficient to use in molecular breeding. However, SSR markers are polymerase chain reaction (PCR) based, with codominant inheritance, and are easy and inexpensive to use in a breeding program (61). Furthermore, whole genome sequencing of cucumber (19) has enabled large-scale development of SSR markers and linkage maps in cucumber $(6,34,38)$. So far, mapping of downy mildew resistance to a chromosome of cucumber has not been reported, and SSR markers with a distance $<5 \mathrm{cM}$ from the resistance gene have not been identified in cucumber. In this paper, a study of chromosomal QTL mapping for downy mildew resistance in cucumber was conducted using 2,360 pairs of SSR primers, and SSR markers that have tight linkage to the resistance were identified.

\section{Materials and Methods}

Plant materials. Two inbred lines, $\mathrm{K} 8$ and $\mathrm{K} 18$, were used as parental lines in this study. Inbred K8 (Yuanfeng-5-160-8-14-19-2) is resistant to cucumber downy mildew, and was derived from a Chinese Long cucumber hybrid, Yuanfeng, which has resistance to downy mildew. Inbred K18 is susceptible to downy mildew (59). $\mathrm{F}_{1}$ progeny were obtained from the cross of $\mathrm{K} 8 \times \mathrm{K} 18$ made in Beijing. $F_{1}$ plants were then self-pollinated to produce $F_{2}$ seeds. One-hundred-forty $\mathrm{F}_{2: 3}$ lines were generated from $140 \mathrm{~F}_{2}$ plants by self-pollination.

Disease resistance screen. The degree of resistance to cucumber downy mildew for each of the parental lines, $\mathrm{K} 8$ and $\mathrm{K} 18$, as well as the $F_{1}$ and $140 \mathrm{~F}_{2: 3}$ lines, was tested two times (in spring and autumn 2009) using an inoculation method. The disease evaluations for $140 \mathrm{~F}_{2}$ plants were done in spring 2004. The specific isolate of $P$. cubensis used in this study was maintained using in vivo host preservation alternated with low temperature freezing preservation, according to the National Agricultural Standards: Rule for Evaluation of Cucumber for Resistance to Downy Mildew, NY/T 1857.2-2010 (http://www.caqs.gov.cn/gg/t20100914_ 836358.htm). The inoculation method involved soaking seeds in $5 \% \mathrm{NaOCl}$ for $10 \mathrm{~min}$, washing them with tap water, placing them on two layers of filter paper in petri dishes, and germinating them in an incubator at $28^{\circ} \mathrm{C}$. When the average radicle length was $5 \mathrm{~mm}$, the seeds were sown individually into plastic pots filled with a steamsterilized propagation substrate composed of peat, vermiculite, and soil from vegetable fields $(2: 1: 1$, volume basis) that had been steamsterilized at $134^{\circ} \mathrm{C}$ for $30 \mathrm{~min}$. Seedlings were placed in a growth chamber at $25 / 20^{\circ} \mathrm{C}$ day/night with a $16-\mathrm{h}$ photoperiod. Illumination was provided by high-pressure sodium lamps at $50 \mathrm{~W} / \mathrm{M}^{2}$.

The seedlings were arranged randomly with three replications of 10 plants each. The resistant cultivar Jinyan No. 2 and the susceptible cultivar Xintaimici were used as control treatments according to the National Agricultural Standards: Rule for Evaluation of $\mathrm{Cu}-$ cumber for Resistance to Downy Mildew, NY/T 1857.2-2010 (http://www.caqs.gov.cn/gg/t20100914_836358.htm). All seedlings were inoculated at the stage of a fully opened second true leaf with the strain of $P$. cubensis known to be epidemic in China (5), collected from cucumber plants at the Nankou experimental farm in Beijing. Both sides of each leaf of the seedlings were sprayed uniformly using a hand-pumped sprayer (YH-038, YUANHUA PENWU Factory, Taizhou, Zhejiang, China) to the point of run-off. The inoculum concentration used was $8 \times 10^{4}$ sporangia $/ \mathrm{ml}$. After inoculation, plants were kept in the dark at $100 \%$ relative humidity (RH) for $24 \mathrm{~h}$, followed by 7 to 10 days at $80 / 100 \% \mathrm{RH}$ by day/night at a temperature of 20 to $23^{\circ} \mathrm{C}$.
Symptom assessment. Disease resistance was rated 10 days after inoculation, and a disease index (DI) was calculated as a weighted mean according to the formula: $\mathrm{DI}=100 \times \sum$ (Number of plants with disease rating $\times$ Disease rating)/(Total number of plants $\times$ Highest disease rating possible). The disease rating scale for each seedling was as follows: $0=$ absence of symptoms; $1=$ $\leq 1 / 10$ th of all leaves with downy mildew spots; $2=\geq 1 / 10$ but $\leq$ $1 / 4$ of all leaves with downy mildew; $3=\geq 1 / 4$ but $\leq 1 / 2$ of all leaves with symptoms; $4=\geq 1 / 2$ but $\leq 3 / 4$ of all leaves with downy mildew; $5=\geq 3 / 4$ of all leaves with downy mildew, or the whole leaf dead. Downy mildew resistance for each line was determined using the DI. Seedlings with a rating of $0<$ DI $\leq 15$ were classified as highly resistant, $15<$ DI $\leq 35=$ moderately resistant, $35<\mathrm{DI} \leq 55=$ slightly resistant, $55<\mathrm{DI} \leq 75=$ moderately susceptible, and $75<$ DI $=$ highly susceptible. The first and second true leaves on a cucumber plant normally differ in reaction to downy mildew, especially for resistant lines (5), but each plant was rated based on all the leaves on the plant, including the first and second true leaves.

SSR marker analysis. DNA was extracted from young leaf tissue of plants of the parental lines, the $F_{1}$ plants, and each plant in the $\mathrm{F}_{2}$ population using a CTAB extraction procedure $(29,45)$. DNA concentration was estimated on a $1 \%$ agarose gel with $1 \times$ TEA buffer, stained with ethidium bromide. For each plant sample, each 15- $\mu$ PCR reaction contained $8.02 \mu \mathrm{l}$ double distilled water $\left(\mathrm{ddH}_{2} \mathrm{O}\right), 1.5 \mu \mathrm{l} 10 \times$ buffer, $0.2 \mu \mathrm{l}$ dNTPs $(10 \mathrm{mM}), 0.08 \mu \mathrm{l} \mathrm{Taq}$ DNA polymerase $(10 \mathrm{U} / \mu \mathrm{l}), 0.6 \mu \mathrm{l}$ primer $\mathrm{F}(50 \mathrm{ng} / \mu \mathrm{l}), 0.6 \mu \mathrm{l}$ primer R (50 ng/ $\mu \mathrm{l})$, and $4.0 \mu \mathrm{l}$ DNA $(10 \mathrm{ng} / \mu \mathrm{l})$. The PCR amplifications were performed using a GeneAmp PCR system 9700 (Applied Biosystems Inc., Foster City, CA) as follows: $94^{\circ} \mathrm{C}$ for 4 min; 35 cycles of $94^{\circ} \mathrm{C}$ for $15 \mathrm{~s}, 55^{\circ} \mathrm{C}$ for $15 \mathrm{~s}$, and $72^{\circ} \mathrm{C}$ for $30 \mathrm{~s}$; and a final extension at $72^{\circ} \mathrm{C}$ for $5 \mathrm{~min}$. Subsequently, $3 \mu \mathrm{l}$ of the PCR product was subjected to electrophoresis in a $6 \%$ polyacrylamide gel according to the method used by Sambrook and Russell (41).

Bulked segregant analysis (BSA) (35) was performed to screen polymorphic SSR markers associated with cucumber downy mildew resistance. Equal amounts of DNA were pooled separately from six resistant and six susceptible $\mathrm{F}_{2}$ plants. A total of 2,360 pairs of SSR primers was screened to identify polymorphisms between the parental lines (K8 and K18). The development of SSR primers used in this study was described by Ren et al. (38). PCR assays using identified polymorphic SSR primers between the two bulk populations were conducted with DNA from individual plants of the $F_{2}$ population to collect data for genetic mapping analysis.

QTL mapping. JoinMap Version 3.0 (52) was used to develop linkage groups (LGs). Chromosomal assignment of the LGs was based on common markers between the cultivated cucumber map (34) and the high-resolution cucumber genetic map produced by Ren et al. (38). Marker data were assigned to LGs using a minimum logarithm of odds (LOD)-likelihood score of 2.5. The Kosambi map function (25) was used to calculate the genetic distance between markers. An interval mapping analysis $(26,50)$ was conducted using MapQTL 4.0 (51) to detect QTLs, and the locus of the QTL was named by an abbreviation of the trait followed by the chromosome number and locus number.

Sequence annotation and gene prediction in genomic regions harboring QTL. Based on the whole genome sequence of the cucumber inbred line 9930 (19), genomic DNA regions for the locations of QTL were annotated. The DNA sequences were aligned to the cucumber genome sequences using BLASTN at an E-value cutoff of $1 \times 10$ to $1 \times 20$. Only matches with an identity of $\geq 95 \%$ were retained. Gene prediction was performed with the computer program BGF (http://bgf.genomics.org.cn) and veriWed by FGENESH (http://linuxl.softberry.com/) (40), GENESCAN (http://genes.mit.edu/GENSCAN.html) (4), TwinScan (http:// mblab.wustl.edu/software/download/) (24), and then checked manually. InterProScan (http://www.ebi.ac.uk/InterProScan) (58) was used for gene annotation. 


\section{Results}

Cucumber downy mildew resistance for the progeny of $\mathrm{K8} \times$ K18. The disease indices for line K8 in spring 2004, spring 2009, and autumn 2009 were $14.07 \pm 0.99,10.97 \pm 1.56$, and $17.45 \pm$ 0.78 , respectively; the disease indices for line K18 in the three seasons were $83.35 \pm 1.92,58.60 \pm 1.65$, and $56.06 \pm 2.04$, respectively (Table 1 ). The main reason for such large variation among seasons was probably environmental effects. In the first season (spring 2004), all the plants (including the parental lines, $F_{1}$ and $F_{2}$ populations) were severely infected by the pathogen. But in the second and third seasons, disease symptoms were not so severe because of a less favorable environment for the downy mildew pathogen. The disease indices for the two control lines, Jinyan No. 2 and Xintaimici, were $16.15 \pm 0.87,12.30 \pm 1.25$, and $15.68 \pm$ 1.16 , and $81.12 \pm 1.34,76.54 \pm 2.52$, and $78.92 \pm 1.76$, respectively. Thus, K8 was confirmed to be resistant and K18 susceptible to the isolate of $P$. cubensis used in this study. The disease indices for the $F_{1}$ population in the three seasons were $61.33 \pm 0.85,47.40$ \pm 1.34 , and $39.60 \pm 1.97$, respectively, which was between the disease indices of the parental lines each season with a tendency toward the index of the susceptible parent. Frequency distributions of the disease indices for downy mildew in the $\mathrm{K} 8 \times \mathrm{K} 18 \mathrm{~F}_{2}$ populations and $\mathrm{F}_{2 \cdot 3}$ lines in spring 2004, spring 2009, and autumn 2009 had normal distributions ranging from resistant to susceptible phenotypes (Fig. 1), not for a genetic model of two $\left(X^{2}=56.815>\right.$ $\left.X_{0.05,3}^{2}=7.815\right)$ or three $\left(X^{2}=127.326>X_{0.05,7}^{2}=14.067\right)$ genes for resistance as calculated by chi-square analyses. These results indicated that downy mildew resistance in $\mathrm{K} 8$ was quantitative. Thus, QTL analysis was used for downy mildew resistance assessment in this population.

Construction of SSR marker linkages. Molecular analysis performed on cucumber lines K8 and K18 using the SSR method resulted in identification of 322 primers generating polymorphic amplicons from a total of 2,360 pairs of SSR primers. The polymorphic rate was $13.6 \%$. Twenty-three of 322 SSR markers showed polymorphism between the bulk populations. Therefore, these 23 markers and another 30 SSR markers that showed polymorphism in the $F_{2}$ populations were used for screening 140 plants of the $F_{2}$ population for linkage mapping. The resulting genetic map had eight LGs with 39 SSR loci spanning $287.4 \mathrm{cM}$. The average marker interval was $7.37 \mathrm{cM}$. The longest linkage was LG3, spanning $79.2 \mathrm{cM}$ with seven SSR markers. The shortest linkage was LG7, spanning $7.7 \mathrm{cM}$ with two SSR markers (Fig. 2).

SSR markers used in this study were developed from whole genome shotgun sequences, and were the same as those mapped for the integrated genetic and cytogenetic map constructed in 2009 (38). The seven LGs in that map were assigned to the seven corresponding cucumber chromosomes using fluorescence in situ hybridization (FISH) technology (38). In this study, assignment of chromosomes of the eight LGs was based on common markers between the present map and that of Ren et al. (38). LG4 and LG5 were assigned to chromosome 3 (Chr.3); LG7 and LG8 to Chr.4; and LG1, LG2, LG3, and LG6 to Chr.1, Chr.6, Chr.5, and Chr.2, respectively (Fig. 2).

QTL mapping of downy mildew resistance. Using the SSR linkage map, two QTLs for downy mildew resistance were de- tected in spring 2004 using 140 plants of the $F_{2}$ generation. The QTL $d m 1.1$ on Chr.1 was placed in the marker interval between SSR31116 and SSR20705 at genetic distances of 5.0 and $10.5 \mathrm{cM}$, respectively. This QTL accounted for $18.6 \%$ of the total phenotypic variance with a LOD of 6.68. Another QTL, $d m 5.3$, was located on Chr.5 and flanked by SSR00772 and SSR11012 with an $R^{2}$ of $19.5 \%$ and LOD of 6.90 . The genetic distance between $d m 5.3$ and SSR00772, and between $d m 5.3$ and SSR11012 was 5.0 and $15.7 \mathrm{cM}$, respectively (Table 2). Cumulatively, the two QTL explained $38.1 \%$ of the phenotypic variation in the $\mathrm{K} 8 \times \mathrm{K} 18 \mathrm{~F}_{2}$ population.

Two QTLs (dm6.1 and $d m 5.2$ ) were identified in the $140 \mathrm{~F}_{2: 3}$ lines grown in spring 2009. Locus $d m 6.1$ was at the position of SSR16882 on Chr.6, and accounted for $7.6 \%$ of the total phenotypic variance with a LOD of 2.81. Locus $d m 5.2$ was in the region of SSR11012 to SSR16110 on Chr.5 with genetic distances of 10.0 and $13.8 \mathrm{cM}$, respectively. QTL $d m 5.2$ explained $10.7 \%$ of the phenotypic variation with a LOD of 2.78 (Table 2).

There was only one QTL, $d m 5.1$, screened in the $140 \mathrm{~F}_{2: 3}$ lines grown in autumn 2009. QTL $d m 5.1$ was at the position of SSR16110 and explained $19.6 \%$ of the phenotypic variation with a LOD of 6.34 (Table 2). In summary, this study identified a total of five QTLs for downy mildew resistance in the $\mathrm{K} 8 \times \mathrm{K} 18 \mathrm{~F}_{2}$
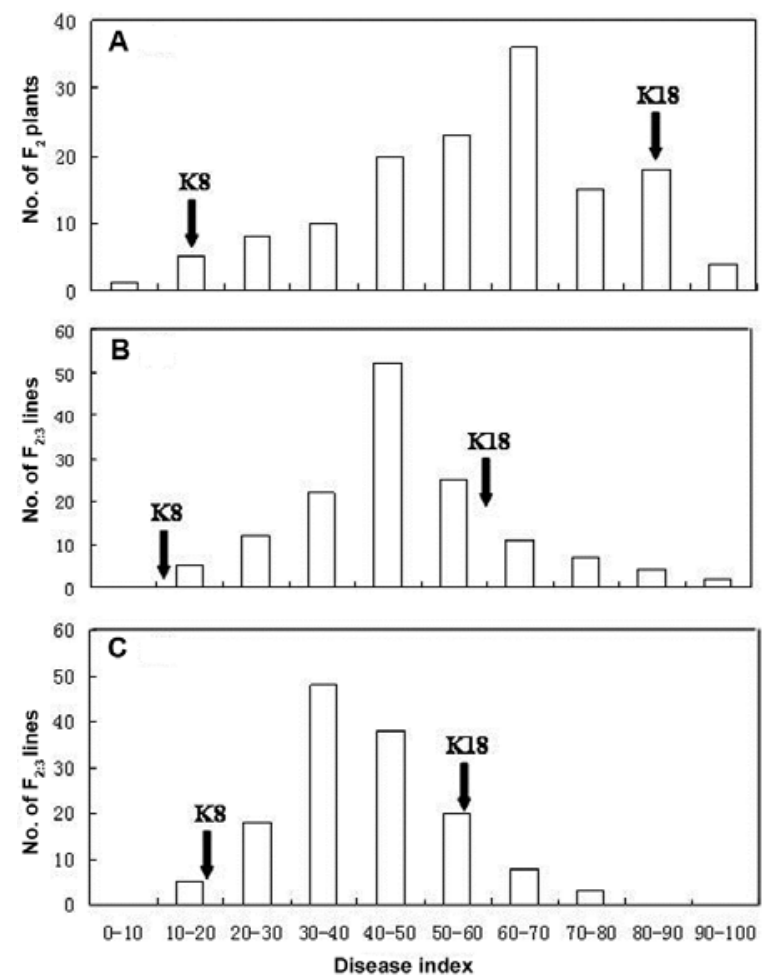

Fig. 1. Frequency distributions of downy mildew severity (index) of cucumber in the K8 $\times$ K18 (resistant $\times$ susceptible cross) $F_{2}$ populations and $F_{2: 3}$ lines. The frequency distributions in A, spring 2004, B, spring 2009, and C, autumn 2009 trials. Each had a normal distribution ranging from resistant to susceptible phenotypes. Mean index ratings for the parental lines are indicated by arrows.

Table 1. Downy mildew severity (disease) index of cucumber parental lines $\mathrm{K} 8$ and $\mathrm{K} 18, \mathrm{~K} 8 \times \mathrm{K} 18 \mathrm{~F}_{1}$ generation, and some genetic factors in the $\mathrm{F}_{2} / \mathrm{F}_{2: 3}$ populations in three seasons

\begin{tabular}{|c|c|c|c|c|c|c|c|}
\hline \multirow[b]{2}{*}{ Season } & \multicolumn{3}{|c|}{ Parental lines } & \multicolumn{4}{|c|}{$F_{2}$ populations } \\
\hline & K8 & K18 & $F_{1}$ & Mean & Standard deviation & Kurtosis $^{\mathbf{a}}$ & Skewness $^{\mathrm{b}}$ \\
\hline Spring 2004 & $14.07 \pm 0.99$ & $83.35 \pm 1.92$ & $61.33 \pm 0.85$ & 57.40 & 19.41 & -0.44 & -0.28 \\
\hline Spring 2009 & $10.97 \pm 1.56$ & $58.60 \pm 1.65$ & $41.70 \pm 1.34$ & 45.06 & 12.38 & 0.60 & 0.12 \\
\hline Autumn 2009 & $17.45 \pm 0.78$ & $56.06 \pm 2.04$ & $39.60 \pm 1.97$ & 37.48 & 6.11 & 0.17 & 0.37 \\
\hline
\end{tabular}

a Kurtosis: measure of symmetry.

b Skewness: measure of whether the data are peaked or flat relative to a normal distribution (http://www.itl.nist.gov/div898/handbook/eda/ section3/eda35b.htm). 
population and $\mathrm{F}_{2: 3}$ lines tested over three seasons. Three QTLs, $d m 5.1, d m 5.2$, and $d m 5.3$, located together on Chr.5 between SSR16110 and SSR00772, each explained $>10 \%$ of the phenotypic variation in resistance to downy mildew. The major QTL for downy mildew resistance was, therefore, located on Chr.5. There were at least two minor QTLs, on Chr.1 and Chr.6. The additive effects for these five QTLs were all negative, indicating that the QTL reduced downy mildew susceptibility.

Annotation and gene prediction in each QTL region. According to the gene prediction and gene function annotation, the candi-
Chr.1

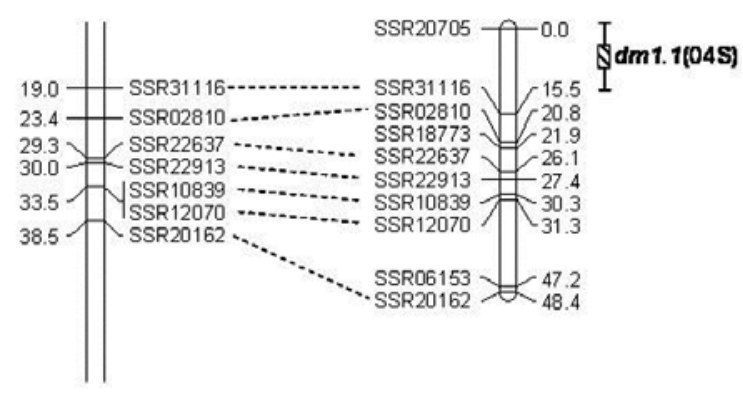

Chr.3
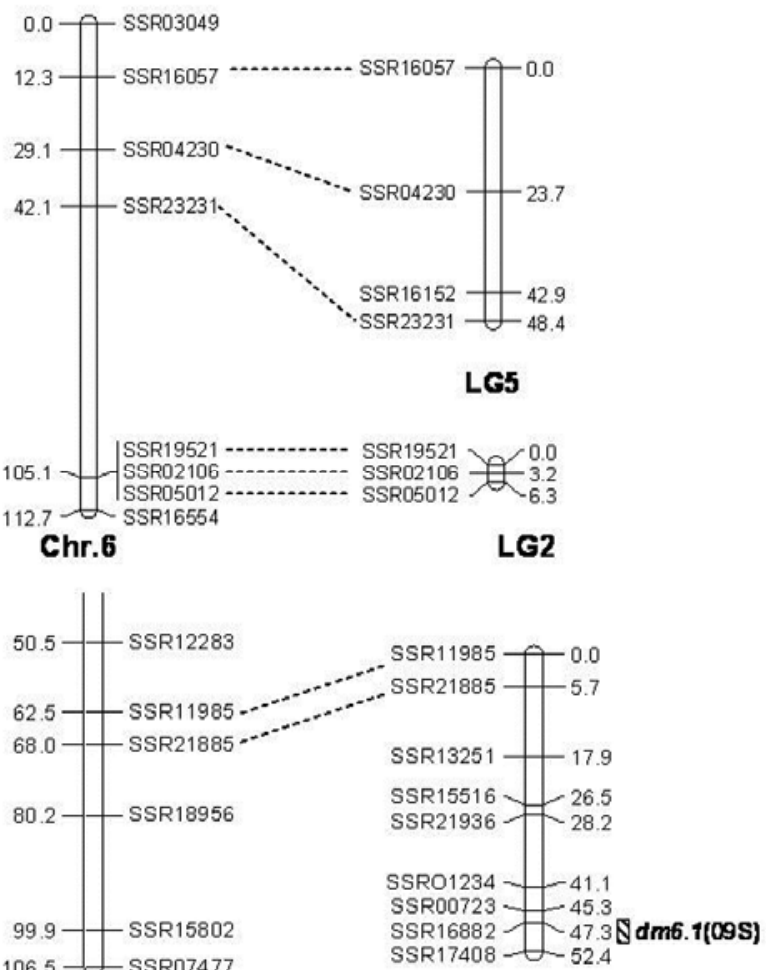

Chr.2

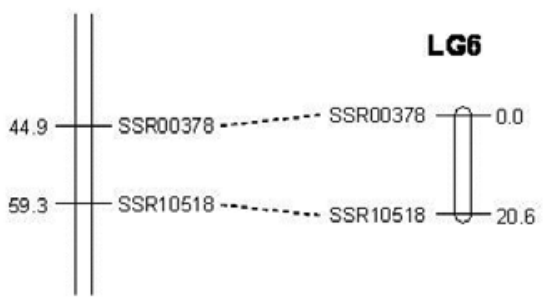

Chr.4

LG8

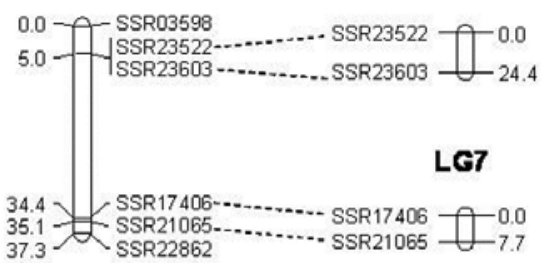

Chr.5

LG3

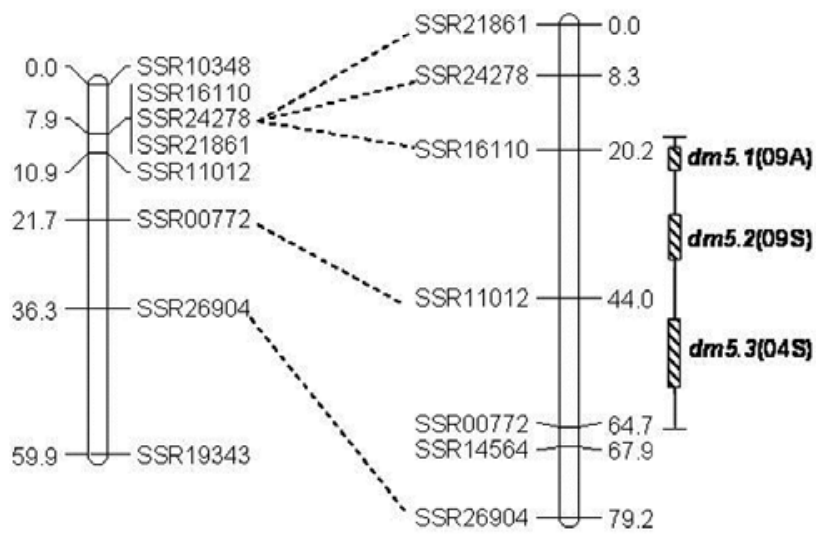

Fig. 2. Construction of simple sequence repeat (SSR) linkage groups and chromosomal quantitative trait locus (QTL) mapping for downy mildew resistance in cucumber line K8, resistant to downy mildew. Five QTLs for downy mildew resistance were detected in three different seasons of screening for resistance in the K8 $\times$ K18 cross and subsequent generations: $d m 1.1$ and $d m 5.3$ were detected in spring 2004, dm5.2 and dm6.1 in spring 2009, and dm5.1 in autumn 2009 . The loci of $d m 1.1$ and $d m 6.1$ were on chromosome 1 (Chr.1) and Chr.6, respectively. The loci of $d m 5.1, d m$ 5.2, and dm5.3 were linked together on Chr.5. Left: Chr. 1 to Chr.6 from the cross of Gy14 x PI 183967 (38) integrated genetic and cytogenetic map; Right: SSR linkage group for $\mathrm{K} 8 \times \mathrm{K}_{18} \mathrm{~F}_{2}$ populations (developed in this study).

Table 2. Quantitative trait locus (QTL) analysis of downy mildew resistance genes in cucumber line K8 for three seasons

\begin{tabular}{|c|c|c|c|c|c|c|c|}
\hline Season & $\mathbf{Q T L}^{\mathbf{a}}$ & Chromosome & MQM $^{\mathbf{b}}$ & LOD $^{c}$ & $A E^{d}$ & $\mathbf{D E}^{\mathrm{e}}$ & $\mathbf{R}^{2}(\%)^{\mathbf{f}}$ \\
\hline \multirow[t]{2}{*}{ Spring 2004} & $d m 1.1$ & 1 & SSR31116-SSR20705 & 6.68 & -11.6939 & 5.51414 & 18.6 \\
\hline & $d m 5.3$ & 5 & SSR00772-SSR11012 & 6.90 & -12.7022 & 0.983182 & 19.5 \\
\hline \multirow[t]{2}{*}{ Spring 2009} & dm6.1 & 6 & SSR16882 & 2.81 & -3.87722 & 5.96285 & 7.6 \\
\hline & $d m 5.2$ & 5 & SSR11012-SSR16110 & 2.78 & -5.93055 & 0.831010 & 10.7 \\
\hline Autumn 2009 & $d m 5.1$ & 5 & SSR 16110 & 6.34 & -3.81888 & -0.580167 & 19.6 \\
\hline
\end{tabular}

a Two (dm1.1 and $d m 5.3)$, two ( $d m 6.1$ and $d m 5.2)$, and one QTL ( $d m 5.1)$ were detected in spring 2004, spring 2009, and autumn 2009, respectively.

b MQM: Multiple- QTL model (51).

${ }^{c}$ LOD: minimum logarithm of odds (51).

d AE: additive effect (51).

${ }^{\mathrm{e}} \mathrm{DE}$ : dominant effect (51).

${ }^{\mathrm{f}} \mathrm{R}^{2}$ : contribution rate (51). 
date genes for $d m 1.1, d m 5.1, d m 5.2, d m 5.3$, and $d m 6.1$ were analyzed in the primary mapping region. Locus $d m 1.1$ was flanked by SSR31116 and SSR20705 located on scaffold 000030 and scaffold 000015 of the 9930 draft genome, respectively. The physical distance between the two markers was $4,259 \mathrm{~kb}$, and there were 500 predicted genes of various enzymes, transcription factors, zinc finger domains, Exo70 exocyst complex subunit, and nucleotide binding proteins (Table 3 ). There were no nucleotide binding site (NBS) resistance genes in this region.
Locus $d m 5.1$ was located at the position of SSR16110. The SSR marker SSR 16110 was in the region of 6608865 to 6609246 on the scaffold 000026 without annotation genes. Locus $d m 5.2$ was located in the region of SSR11012 to SSR16110 within the physical distance of $13,718 \mathrm{~kb}$. These two SSR markers were placed on scaffold 000179 and scaffold 000026 . There were 520 predicted genes for synthase, transport proteins, zinc finger domains, peptidase, binding site, and six NBS-type resistance genes (Csa008307, Csa012579, Csa012551, Csa002747, Csa003127,

Table 3. Annotation and gene prediction for each quantitative trait locus (QTL) region for downy mildew resistance in cucumber line K8

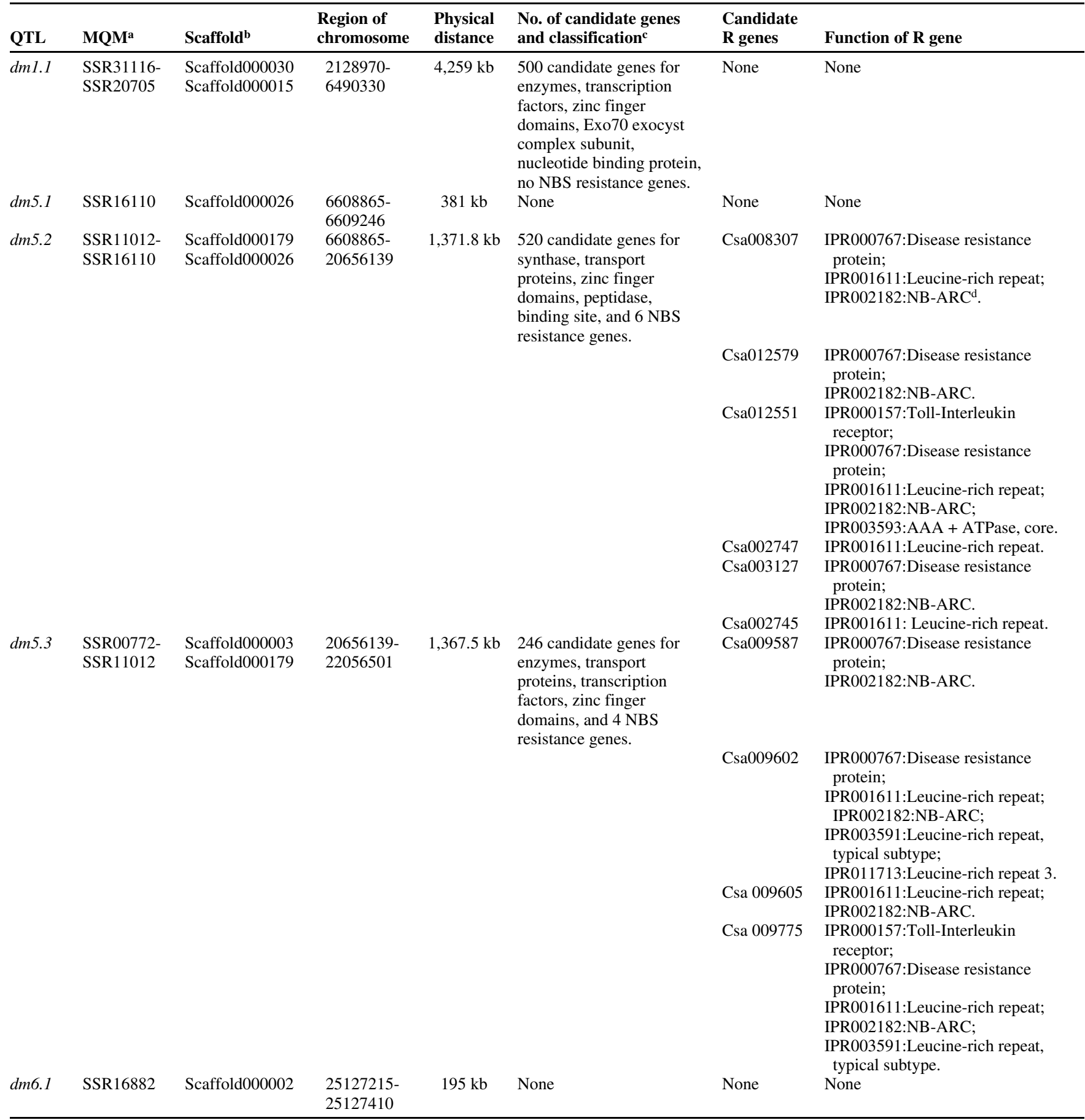

a MQM: Multiple- QTL model (51).

b Scaffold: A portion of the genome sequence reconstructed from end-sequenced whole-genome shotgun clones. Scaffolds are composed of contigs and gaps (http://genome.jgi-psf.org/help/scaffolds.html).

${ }^{\mathrm{c}}$ The candidate genes for $d m 1.1, d m 5.1, d m 5.2, d m 5.3$, and $d m 1.1$ were analyzed in the primary mapping region. In the region of $d m 5.2$, six nucleotide binding site (NBS)-type resistance genes were predicted. Of the 246 genes predicted in the $d m 5.3$ region, four belonged to NBS-type resistance gene analogs (RGAs).

d NB-ARC: nucleotide-binding adaptor shared by APAF-1, R proteins, and CED-4 (www.plantphysiol.org/content/140/4/1233.abstract). 
and Csa002745). The functions of these genes are listed in Table 3 .

Locus $d m 5.3$ was placed in the region of SSR00772 to SSR11012 within $20.7 \mathrm{cM}$ on Chr.5. The physical distance between SSR00772 and SSR11012 was $1,367.5 \mathrm{~kb}$, and there were 246 predicted genes in this region. These genes were for enzymes, transport proteins, transcription factors, zinc finger domains, and four NBS-type disease resistance genes (Csa009587, Csa009602, Csa009605, and Csa009775, Table 3). The latter could be downy mildew resistance candidate genes. Locus $d m 6.1$ was located at the position of SSR16882 in the region of 25127215 to 25127410 with $195 \mathrm{~kb}$ on the scaffold 000002 without annotation genes (Table 3).

\section{Discussion}

Two patterns of inheritance have been reported for resistance to downy mildew in cucumber: quantitative resistance controlled by multiple genes $(1,8,13,21,43,44,59)$, and qualitative resistance controlled by a single gene $(12,14,53,54)$. In this study, resistance to downy mildew in line $\mathrm{K} 8$ was concluded to be quantitative and controlled by multiple genes based on the disease indices analysis for genetic populations derived from $\mathrm{K} 8 \times \mathrm{K} 18$. The two different patterns of inheritance that have been reported may be explained by several factors. First, pathogenicity and race differentiation of isolates of $P$. cubensis have not been clarified for cucumber (5). Second, different cultivars and breeding lines have been used as resistance sources. Third, different disease identification methods and rating scales make it difficult to compare studies. Fourth, development of cucumber downy mildew is strongly affected by environmental conditions, as for many diseases, and maintenance of uniform environmental conditions during testing can be difficult. Fifth, the inheritance of downy mildew resistance appears to be complex. In this study, the inoculum used for screening for susceptibility to downy mildew induced was a single strain of $P$. $\mathrm{Cu}$ bensis. The inoculation method and disease rating scale used were adopted from the National Agricultural Standards in China (NY/T1857.2-2010, http://www.caqs.gov.cn/gg/t20100914_836 358.htm). A growth chamber with precisely controlled lighting, temperature, and humidity was used for inoculations and ratings. $\mathrm{F}_{2}$ and $\mathrm{F}_{2: 3}$ lines were tested for resistance over multiple seasons to maximize the reliability and accuracy of the results.

Commercial cucumber cultivars have a narrow genetic base $(46,49)$. It is also difficult to develop SSR markers without genomic sequence information. Previous studies have reported RFLP, RAPD, and SRAP markers linked to downy mildew resistance $(1,12,18,23,32)$. However, because of the disadvantages of these methods compared to SSR markers and large linkage distances from downy mildew resistance genes, those markers were not good candidates for use in MAS for downy mildew resistance in cucumber. SSR markers are PCR based, and with co-dominant inheritance, are effective and easy to use in breeding programs. SSR markers were used for the first time in cucumber in 2003 (7), and the number of SSR markers was limited. So far, only one SSR marker reported by Bai et al. (1) has been used with a genetic distance of $9.7 \mathrm{cM}$ from a QTL that provided downy mildew resistance in cucumber. This study used 2,360 pairs of SSR primers to map resistance genes for downy mildew in cucumber. Five QTLs for downy mildew resistance were detected in K8: $d m 1.1$ was mapped into the marker interval between SSR31116 and SSR20705 with genetic distances of 5.0 and $10.5 \mathrm{cM}$, respectively; QTL $d m 5.1$ was located at SSR16110; $d m 5.2$ was flanked between SSR11012 and SSR16110; $d m 5.3$ was located in the marker interval between SSR00772 and SSR11012 with genetic distances of 5.0 and $15.7 \mathrm{cM}$, respectively; and $d m 6.1$ was at the position of SSR16882. These six SSR markers will benefit MAS for downy mildew resistance and will be useful for future genetic studies in cucumber.

In cucumber, more than 10 low-resolution molecular linkage maps have been constructed since 2000, with the majority of molecular markers being RAPDs, AFLPs, or SRAPs that are not as useful for plant breeders as SSRs $(3,15-17,30,37,39,47,57)$. Using these maps, several genes in cucumber ( $p r s v, z y m v, B$, and $f f n$ ) and
QTLs for horticultural traits (powdery mildew resistance, parthenocarpy, and multiple lateral branching) were mapped with molecular linkages. But these genes or QTLs were not chromosomal mapped since the linkages of these former maps had not been assigned to chromosomes. Sequencing of the whole cucumber genome (19) has made it possible to use more breeder-friendly molecular markers such as SSRs for genetic mapping and MAS in cucumber $(6,38)$. The usefulness of these cucumber microsatellite markers has been demonstrated in several recent linkage maps $(34,38,56)$. Based on these maps, the genes $d e, l l, u, f r, D, H, b i$, and $C c u$ $(19,22,61)$ were placed onto chromosomes. As for QTL analysis for downy mildew resistance in cucumber, Bai et al. (1) detected four QTLs ( $d m 1.1, d m 1.2, d m 6.1$, and $d m 6.2)$ mapped to linkage groups 1 and 6. But the two LGs could not be assigned to corresponding chromosomes. In this study, chromosomal mapping for downy mildew resistance in cucumber was successfully achieved. Loci $d m 1.1$ and $d m 6.1$ were placed on Chr.1 and Chr.6, respectively. Loci $d m 5.1, d m 5.2$, and $d m 5.3$ were linked on Chr.5. Attempts to do comparison analysis for the QTL detected in the two studies were not successful due to a lack of common molecular markers.

Many disease resistance genes ( $R$ genes) conferring resistance to a diverse array of pathogens, including bacteria, fungi, oomycetes, viruses, and nematodes, have been isolated in plants. The largest $R$ gene family encodes NBS and leucine-rich repeat (LRR) domains $(11,20,31,33)$. These $R$ proteins have been shown to function as intracellular immune receptors that recognize, directly or indirectly, specific pathogen effectors encoded by avirulence (Avr) genes (2). In the 9930 draft genome, 61 NBS-type resistance gene analogs (RGAs) were identified and were distributed mostly in 11 clusters in the cucumber chromosomes (19). In this study, the genomic regions bearing the five QTLs of downy mildew resistance in K8 were annotated. In the region of $d m 5.2$, six NBS-type resistance genes were predicted. Of the 246 genes predicted in the $d m 5.3$ region, four belonged to NBS-type RGAs. However, there were no NBS-type RGAs annotated in the regions of $d m 1.1$, $d m 5.1$, and $d m 6.1$. The 10 NBS-type RGAs will be studied for downy mildew resistance candidate genes. Of the 61 NBS-type RGAs detected in the 9930 draft genome, 16 were distributed in Chr.5 (19), including 10 identified in this study. This may suggest that multiple NBS-LRR type disease resistance genes may be located on this chromosome. Indeed, in a previous study, a major QTL for powdery mildew resistance was co-localized in the $d m 5.3$ region (60). If powdery mildew resistance in cucumber is controlled by NBS-type R genes, the NBS cluster members may condition multiple disease resistances in this region.

\section{Acknowledgments}

This work was supported by the key program of the National Natural Science Foundation of China (Grant No. 31030057); the earmarked fund for Modern Agro-industry Technology Research System (CARS-25); the National Key Basic Research and Development Program of China (2009CB119000); and the Key Laboratory of Biology and Genetic Improvement of Horticultural Crops, Ministry of Agriculture, the People's Republic of China.

\section{Literature Cited}

1. Bai, Z., Yuan, X., Cai, R., Liu, L., He, H., Zhou, H., and Pan, J. 2008. QTL analysis of downy mildew resistance in cucumber. Prog. Nat. Sci. 18:706710. (in Chinese)

2. Bent, A., and Mackey, D. 2007. Elicitors, eVectors and R genes: The new paradigm and a lifetime supply of questions. Annu. Rev. Phytopathol. 45:399-436.

3. Bradeen, J. M., Staub, J. E., Wye, C., Antonise, R., and Peleman, J. 2001 Towards an expanded and integrated linkage map of cucumber (Cucumis sativus L.). Genome 44:111-119.

4. Burge, C., and Karlin, S. 1997. Prediction of complete gene structures in human genomic DNA. J. Mol. Biol. 268:78-94.

5. Cao, Q., Wan, J., and Chen, J. 2007. Research advances on downy mildew resistance in cucumber. China Cucurbits Veget. 1:27-30. (in Chinese)

6. Cavangnaro, P. F., Senalik, D. A., Yang, L. M., Simon, P. W., Harkins, T. T., Kodira, C. D., Huang, S. W., and Weng, Y. 2010. Genome-wide characterization of simple sequence repeats in cucumber (Cucumis sativus L.). BMC Genomics 11:569.

7. Chiba, N., Suwabe, K., Nunome, T., and Hirai, M. 2003. Development of microsatellite markers in melon (Cucumis melo L.) and their application to 
major cucurbit crops. Breed. Sci. 53:21-27.

8. Cochran, F. D. 1938. Breeding cucumbers for resistance to downy mildew. Proc. Am. Soc. Hortic. Sci. 35:541-543.

9. Cohen, Y. 1981. Downy mildew of cucurbits. In: The Downy Mildews. D. M. Spencer, ed. Academic Press, New York.

10. Colucci, S. J., and Holmes, G. J. 2010. Downy mildew of cucurbits. The Plant Health Instructor. DOI: 10.1094/PHI-I-2010-0825-01

11. Dangl, J. L., and Jones, J. D. G. 2001. Plant pathogens and integrated defence responses to infection. Nature 411:826-833.

12. Ding, G., Qin, Z., Zhou, X., and Fan, J. 2007. RAPD and SCAR markers linked to downy mildew resistance genes in cucumber. Acta Botanica Boreali-Occidentalia Sinica 27:1747-1751. (in Chinese)

13. Doruchoowski, R. W., and Lakowska-Ryk, E. 1992. Inheritance of resistance to downy mildew (Pseudoperonospora cubensis) in Cucumis sativus. In: Proc. 5th Eucarpia Cucurbitaceae Sympos., Warsaw Poland:66-69.

14. Fanourakis, N. E., and Simon, P. W. 1987. Analysis of genetic linkage in the cucumber. J. Hered. 78:238-242.

15. Fazio, G., Staub, J. E., and Stevens, M. R. 2003. Genetic mapping and QTL analysis of horticultural traits in cucumber (Cucumis sativus L.) using recombinant inbred lines. Theor. Appl. Genet. 107:864-874.

16. Fukino, N., Yoshioka, Y., Kubo, N., Hira, M., Sugiyama, M., Sakata, Y., and Matsumoto, S. 2008. Development of 101 novel SSR markers and construction of an SSR-based genetic linkage map in cucumber (Cucumis sativus L.). Breed. Sci. 58:475-483.

17. Heang, D., Sato, H., Sassa, H., and Koba, T. 2008. Detection of two QTLs for fruit weight in cucumber (Cucumis sativus L). Pages 511-514 in: Proc IXth EUCARPIA Meeting on Genetics and Breeding of Cucurbitaceae. INRA, Avignon, France.

18. Horejsi, T., Staub, J., and Thomas, C. 2000. Linkage of random amplified polymorphic DNA markers to downy mildew resistance in cucumber $(\mathrm{Cu}$ cumis sativus L.). Euphytica 115:105-113.

19. Huang, S., Li, R., Zhang, Z., Li, L., Gu, X., Fan, W., Lucas, W., Wang, X., Xie, B., Ni, P., Ren, Y., Zhu, H., Li, J., Lin, K., Jin, W., Fei, Z., Li, G., Staub, J. E., Kilian, A., van der Vossen, E. A. G., Wu, Y., Guo, J., He, J., Jia, Z., Ren, Y., Tian, G., Lu, Y., Ruan, J., Qian, W., Wang, M., Huang, Q., Li, B., Xuan, Z., Cao, J., San, A., Wu, Z., Zhang, J., Cai, Q., Bai, Y., Zhao, B., Han, Y., Li, Y., Li, X., Wang, S., Shi, Q., Liu, S., Cho, W., Kim, J., Xu, Y., Heller-Uszynska, K., Miao, H., Cheng, Z., Zhang, S., Wu, J., Yang, Y., Kang, H., Li, M., Liang, H., Ren, X., Shi, Z., Wen, M., Jian, M., Yang, H., Zhang, G., Yang, Z., Chen, R., Liu, S., Li, J., Ma, L., Liu, H., Zhou, Y., Zhao, J., Fang, X., Li, G., Fang, L., Li, Y., Liu, D., Zheng, H., Zhang, Y., Qin, N., Li, Z., Yang, G., Yang, S., Bolund, L., Kristiansen, K., Zheng, H., Li, S., Zhang, X., Yang, H., Wang, J., Sun, R., Zhang, B., Jiang, S., Wang, J., Du, Y., and Li, S. 2009. The genome of the cucumber, Cucumis sativus L. Nat. Genet. 41:1275-1281.

20. Hulbert, S. H., Webb, C. A., Smith, S. M., and Sun, Q. 2001. Resistance gene complexes: Evolution and utilization. Annu. Rev. Phytopathol. 39:285-312.

21. Jenkins, J. M. 1946. Studies on the inheritance of downy mildew resistance. J. Hered. 37:267-276.

22. Kang, H., Weng, Y., Yang, Y., Zhang, Z., Zhang, S., Mao, Z., Cheng, G., Gu, X., Huang, S., and Xie, B. 2010. Fine genetic mapping localizes cucumber scab resistance gene $\mathrm{Ccu}$ into an $\mathrm{R}$ gene cluster. Theor. Appl. Genet. 122:795-803

23. Kennard, W. C., Poetter, K., Dijkhuizen, A., Meglic, V., Staub, J. E., and Havey, M. J. 1994. Linkage among RFLP, RAPD, isozyme, disease resistance and morphological markers in narrow and wide crosses of cucumber. Theor. Appl. Genet. 89:42-48

24. Korf, I., Flicek, P., Duan, D., and Brent, M. R. 2001. Integrating genomic homology into gene structure prediction. Bioinformatics 17:S140-S148.

25. Kosambi, D. D. 1944. The estimation of map distance from recombination values. Ann. Eugen. 12:172-175.

26. Lander, E. S., and Botstein, D. 1989. Mapping Mendelian factors underlying quantitative traits using RFLP linkage maps. Genetics 121:185-199.

27. Lebeda, A. 1991. Resistance of muskmelons to Czechoslovak isolates of Pseudoperonospora cubensis from cucumbers. Sci. Hortic. 45:255-260.

28. Lebeda, A. 1992. Screening of wild Cucumis species against downy mildew isolates from cucumbers. Phytoparasitica 20:203-210.

29. Maniatis, T., Fritsch, E. F., and Sambrook, J. 1982. Molecular Cloning: A Laboratory Manual. Cold Spring Harbor Laboratory, Cold Spring Harbor, NY.

30. Matthew, D. R., Michael, D. C., and Staub, J. E. 2008. Pyramiding QTL for multiple lateral branching in cucumber using inbred backcross lines. Mol. Breed. 22:131-139.

31. McHale, L., Tan, X., Koehl, P., and Michelmore, R. W. 2006. Plant NBSLRR proteins: Adaptable guards. Genome Biol. 7:212.

32. Meglic, V., and Staub, J. E. 1996. Inheritance and linkage relationships of isozyme and morphological loci in cucumber (Cucumis sativus L.). Theor. Appl. Genet. 92:865-872.

33. Meyers, B. C., Kozik, A., Griego, A., Kuang, H., and Michelmore, R. W. 2003. Genome-wide analysis of NBS-LRR-encoding genes in Arabidopsis. Plant Cell Online 15:809.

34. Miao, H., Zhang, S., Wang, X., Zhang, Z., Li, M., Mu, S., Cheng, Z., Zhang, R., Huang, S., Xie, B., Fang, Z., Zhang, Z., Weng, Y., and Gu, X. 2011. A linkage map of cultivated cucumber (Cucumis sativus L.) with 248 microsatellite marker loci and seven genes for horticulturally important traits. Euphytica 182:167-176.

35. Michelmore, R. W., Paran, I., and Kesseli, R. V. 1991. Identification of markers linked to disease resistance genes by bulked segregant analysis: A rapid method to detect markers in specific genomic regions by using segregating populations. Proc. Natl. Acad. Sci. 88:9828-9832.

36. Palti, J. 1974. The significance of pronounced divergences in the distribution of Pseudoperonospora cubensis on its crop hosts. Phytoparasitica 2:109-115.

37. Park, Y. H., Sensoy, S., Wye, C., Antonise, R., Peleman, J., and Havey, M. J. 2000. A genetic map of cucumber composed of RAPDs, RFLPs, AFLPs and loci conditioning resistance to papaya ring spot and zucchini yellow mosaic viruses. Genome 43:1003-1010.

38. Ren, Y., Zhang, Z., Liu, J., Staub, J. E., Han, Y., Cheng, Z., Li, X., Lu, J., Miao, H., Kang, H., Xie, B., Gu, X., Wang, X., Du, Y., Jin, W., and Huang, S. 2009. An integrated genetic and cytogenetic map of the cucumber genome. PLoS ONE 4:e5795.

39. Sakata, Y., Kubcl, N., and Morishita, M. 2006. QTL analysis of powdery mildew resistance in cucumber (Cucumis sativus L.). Theor. Appl. Genet. 112:243-250.

40. Salamov, A. A., and Solovyev, V. V. 2000. Ab initio gene finding in Drosophila genomic DNA. Cold Spring Harbor Laboratory, New York.

41. Sambrook, J., and Russell, D. W. 2001. Molecular Cloning: A Laboratory Manual, 3rd ed. Cold Spring Harbor Laboratory, Cold Spring Harbor, NY.

42. Shetty, N. V., Wehner, T. C., Thomas, C. E., Doruchowski, R. W., and Shetty, K. P. V. 2002. Evidence for downy mildew races in cucumber tested in Asia, Europe, and North America. Sci. Hortic. 94:231-239.

43. Shimizu, S., Kanazawa, K., Kato, A., and Yokata, Y. 1962. Studies on breeding cucumber for resistance to Pseudoperonospora cubensis. Bull Hortic. Res. Stn. Hiratsuka Ser. 1:175-183.

44. Shimizu, S., Kanazawa, K., Kato, A., and Yokata, Y. 1963. Studies on breeding cucumber for resistance to Pseudoperonospora cubensis. Bull Hortic. Res. Stn. Hiratsuka Ser. 2:47-64, 65-81.

45. Staub, J. E., Bacher, J., and Poetter, K. 1996. Sources of potential errors in the application of random amplified polymorphic DNAs in cucumber. HortScience 31:262-266.

46. Staub, J. E., Chung, S. M., and Fazio, G. 2005. Conformity and genetic relatedness estimation in crop species having a narrow genetic base: The case of cucumber (Cucumis sativus L.). Plant Breed. 124:44-53.

47. Sun, Z., Staub, J. E., and Chung, S. M. 2006. Identification and comparative analysis of quantitative trait loci associated with parthenocarpy in processing cucumber. Plant Breed. 125:281-287.

48. Thomas, C. E. 1986. Downy and powdery mildew resistant muskmelon breeding line Mr-1. HortScience 21:329.

49. Thomas, H., and Staub, J. E. 1999. Genetic variation in cucumber (Cucumis sativus L.) as assessed by random amplified polymorphic DNA. Genetic Res. Crop Evol. 46:337-350.

50. Van Ooijen, J. W. 1992. Accuracy of mapping quantitative trait loci in autogamous species. Theor. Appl. Genet. 84:803-811.

51. Van Ooijen, J. W., Boer, M. P., Jansen, R. C., and Maliepaard, C. 2000 MapQTL Version 4.0, Software for the Calculation of QTL Positions on Genetic Maps. Plant Research International, Wageningen, The Netherlands.

52. Van Ooijen, J., and Voorrips, R. 2001. JoinMap 3.0, Software for Calculation of Genetic Linkage Maps. Plant Research International, Wageningen, The Netherlands.

53. Van Vliet, G. J. A., and Meysing, W. D. 1974. Inheritance of resistance to Pseudoperonospora cubensis Rost. in cucumber (Cucumis sativus L.). Euphytica 23:251-255.

54. Van Vliet, G. J. A., and Meysing, W. D. 1977. Relation in the inheritance of resistance to Pseudoperonospora cubensis Rost. and Sphaerotheca fuliginea Poll. in cucumber (Cucumis sativus L.). Euphytica 26:793-796.

55. Wehner, T. C., and Shetty, N. V. 1987. Downy mildew resistance of the cucumber germplasm collection in North Carolina field tests. Crop Sci. 37:1331-1340.

56. Weng, Y., Johnson, S., Staub, J. E., and Huang, S. 2010. An extended microsatellite genetic map of cucumber, Cucumis sativus L. HortScience 45:880-886.

57. Yuan, X. J., Pan, J. S., Cai, R., Guan, Y., and Liu, L. Z. 2008. Genetic mapping and QTL analysis of fruit and flower related traits in cucumber (Cucumis sativus L.) using recombinant inbred lines. Euphytica 164:473491.

58. Zdobnov, E. M., and Apweiler, R. 2001. InterProScan - an integration platform for the signature-recognition methods in InterPro. Oxford University Press, Oxford

59. Zhang, S. Q., Gu, X. F., Zhang, S. P., and Zou, Z. R. 2007. Genetic analysis of downy mildew resistance in cucumber. Acta Botanica BorealiOccidentalia Sinica 27:2416-2420.

60. Zhang, S., Liu, M., Miao, H., Zhang, S., Yang, Y., Xie, B., and Gu, X. 2011 QTL mapping of resistance genes to powdery mildew in cucumber (Cucumis sativus L.). Sci. Agric. Sin. 44:3584-3593. (in Chinese)

61. Zhang, S., Miao, H., Gu, X., Yang, Y., Xie, B., Wang, X., Huang, S., Du, Y, Sun, R., and Wehner, T. C. 2010. Genetic mapping of the scab resistance gene $(C c u)$ in cucumber (Cucumis sativus L.). J. Am. Soc. Hortic. Sci. $135: 53-58$ 